\title{
Analisis Kompetensi Pedagogik Guru Biologi SMA Se-Kota Binjai
}

\author{
Mariana Siregar ${ }^{1}$ Fauziyah Harahap $^{2}$ Herbert Sipahutar ${ }^{2}$ \\ ${ }^{1}$ Guru Biologi di SMA Negeri 1 Binjai Jln. WR. Mongonsidi No. 10 Binjai Kota \\ ${ }^{2}$ Program Studi Pendidikan Biologi Pascasarjana Universitas Negeri Medan, Sumatera Utara, Indonesia \\ E-mail: marianasiregar543@gmail.com
}

\begin{abstract}
The research was aim to know pedagogic competence teachers' and factors relating to the competence of teachers. The population in this study are all biology teachers at 20 schools. The research sample as many as 34 teachers of biology. Data was collected by observation sheet, assessment lesson plan sheet, teacher questionnaire and data analyze were qualitative descriptive.The result revealed teacher pedagogic competence in arrange lesson plan was 11 persons $(32.35 \%)$ categorized very good, 23 persons $(67,65 \%)$ is good and the total average value 80,32 is good. Learning performance was 14 persons $(41,18 \%)$ categorized very good and 20 persons $(58,82 \%)$ is good and the total average value 80,68 is good.Factors that influence the pedagogical competence of teachers is level education background with compile lesson plan was 0.037 , frequency certification acceptance was 0.025 . An frequency activity of MGMP with learning performance was 0.012 .
\end{abstract}

Keywords: Biology teacher, Pedagogic competence, Professional competence and Factors Pedagogic Competence.

\section{PENDAHULUAN}

Indonesia adalah merupakan salah satu negara yang sangat mengedepankan pendidikan sebagai bagian penting dalam salah satu sektor pembangunan bangsa. Pendidikan menjadi hal yang sangat penting dalam menciptakan dan membentuk generasi masa depan. Menurut Arikunto, 2008 menyatakan bahwa pendidikan bertujuan (1) meningkatkan kinerja siswa sekolah dalam perannya sebagai peserta didik yang belajar dengan semangat tinggi agar dapat mencapai prestasi belajar yang optimal; (2) meningkatkan mutu kinerja guru sehingga mampu membimbing guru dan siswa; (3) meningkatkan keefektifan kurikulum; (4) meningkatkan keefektifan dan keefisienan saran dan prasarana; (5) meningkatkan kualitas pengelola sekolah; dan (6) meningkatkan kualitas situasi umum sekolah.

Guru merupakan elemen kunci dalam sistem pendidikan, khususnya di sekolah.Komponen-kompenen lain seperti kurikulum, sarana-prasarana, biaya dan sebagainya tidak akan memberikan arti apabila esensi pembelajaran yang terletak pada interaksi guru dengan peserta didik tidak berkualitas.Menciptakan seorang guru yang berkompeten tidaklah merupakan pekerjaan yang mudah, memerlukan waktu yang lama agar setiap guru memiliki kompetensi yang harus dicerminkan dalam sikap, pola dan tindakan sehari-hari.Sagala (2008) mengatakan bahwa kompetensi adalah perpaduan dari penguasaan pengetahuan, keterampilan, nilai dan sikap yang direfleksikan dalam kebiasan berpikir dan bertindak dalam melaksanakan tugas dan pekerjaannya.

Kompetensi pedagogik pada dasarnya merupakan kemampuan guru di dalam mengelola pembelajaran. Pada proses pembelajaran, guru merupakan sebagai fasilitator bagi peserta didik dalam kegiatan perencanaan, pelaksanaan dan evaluasi pembelajaran.Interaksi yang terjadi antara guru dengan peserta didik merupakanfaktor utama bagi terciptanyakegiatan pembelajaran, pendorong dan pembimbing dalam kegiatan pembelajaran.Kompetensi pedagogik guru merupakan kemampuan yang harus dimiliki oleh guru secara memadai dalam mengelola proses pembelajaran sehingga guru mampu menciptakan suasana pembelajaran yang bervariasi, aktif, inovatif, kreatif, efektif dan menyenangkan.Kompetensi tersebut dapat menyebabkan peserta didik akan tertarik dalam mengikuti proses pembelajaran yang berlangsung di dalam 
kelas, sehingga siswa akan berusaha untuk mampu membelajarkan diri sendiri di luar kelas atau sekolah. Sehingga hal tersebut akan mampu meningkatkan mutu pembelajaran peserta didik itu sendiri.

Menurut Spencer \& Spencer (1993) dalam Musfah (2011) kompetensi guru merupakansalah satu faktor yang mempengaruhi tercapainya tujuan pembelajaran dan pendidikan di sekolah. Kompetensi guru dinilai penting sebagai alat seleksi dalam penerimaan calon guru yangdapat dijadikan sebagai pedoman dalam rangka pembinaan dan pengembangan tenaga guru.Kompetensi yang harus dikuasai seorang guru menurut Undang-Undang Guru dan Dosen Nomor 14 Tahun 2005yaitu: (a) kompetensi pedagogik; (b) kompetensi sosial; (c) kompetensi kepribadian; dan (d) kompetensi profesional.

Berdasarkan empat kompetensi tersebut, kompetensi guru secara teoritis dan praktis memiliki manfaat yang sangat penting terutama dalam meningkatkan kualitas pendidikan. Analisis kompetensi guru dapat dijadikan (1) sebagai alat untuk mengembangkan standart kemampuan profesional guru; (2) merupakan alat seleksi penerimaan guru; (3) untuk pengelompokkan guru; (4) sebagai bahan acuan dalam pengembangan kurikulum; (5) merupakan alat pembinaan guru; dan (6) mendorong kegiatan dan hasil belajar (Mulyasa, 2008).

Undang- Undang Guru BAB IV Pasal 8 Tahun 2005 bahwa guru wajib memiliki kualifikasi akademik, kompetensi, sertifikat pendidik, sehat jasmani, dan rohani serta memiliki kemampuan untuk mewujudkan tujuan pendidikan nasional.Hal terpenting dalam meningkatkan mutu pendidikan adalah faktor guru sendiri, karena guru memiliki peran yaitu sebagai pendidik, pengajar, pembimbing, pelatih, penasehat, pembaharu (inovator), pemotivasi (motivator), serta pengevaluasi (evaluator) Mulyasa, 2007.Faktor-faktor kegiatan guru diluar pembelajaran seperti mengikuti berbagai macam kegiatan yang menunjang kemajuan mempunyai peranan dalam kompetensi guru.Kompetensi guru tidak dapat berdiri sendiri, namun dipengaruhi oleh faktor-faktor lain, seperti latar belakang pendidikan, pengalaman mengajar dan lama mengajar.Pemerintah melakukan UKA (Uji Kompetensi Awal) dan UKG (Uji KOmpetensi Guru) untuk seluruh guru yang terdiri dari soal kemampuan pedagogik dan profesional untuk meningkatkan kemampuan guru.

Berdasarkan fenomena diatas, penulis tertarik untuk mengadakan penelitian terhadap kemampuan pedagogik guru biologi dan faktor-faktor yang mempengaruhinya di SMA Se-Kota Binjai.

\section{METODE PENELITIAN}

Penelitian ini merupakan penelitian deskriptifyang bertujuan untuk melihat kompetensi pedagogik dan faktor-faktor yang mempengaruhinya. Populasi dalam penelitian ini adalah guru Biologi SMA SeKota Binjai yang terdiri dari 20 sekolah. Sampel yang menjadi objek penelitian ini berjumlah 34 orang guru biologi, yang mewakili guru yang mengajar di kelas $\mathrm{X}$, XI dan XII. Data dikumpulkan dengan penilaian RPP, observasi proses pembelajaran dan angket tertutup. Hasil kompetensi pedagogik diberikan penskoran dengan menggunakan skala likert 1-5 dan jawaban lembar angket yang berhubungan dengan faktor-faktor kompetensi dikategorikan dalam bentuk angka dengan rentang 1-4 untuk masing-masing pilihan jawaban. Jawaban dianalisis dengan rumus sebagai berikut:

$$
\mathrm{P}=\frac{f}{N} \times 100 \%
$$

\section{Keterangan:}

$\mathrm{P}=$ Persentase hasil jawaban responden

$\mathrm{F}=$ Frekuensi

$\mathrm{N}=$ Banyaknya responden

Setelah penghitungan persentase jawaban, kemudian dijawaban diberikan nilai yaitu:

$$
\text { Nilai }=\frac{\text { Skor Total Perolehan }}{\text { Skor Maksimum }} \times 100
$$

Data hubungan kompetensi pedagogik dengan faktor-faktor kompetensi dianalisis 
dengan uji Chi-Square. Data kompetensi sebagai berikut dengan berpedoman pada pedagogik dikategorikan dengan rentang Tabel 1.dan Tabel 2.

Tabel 1. Kriteria Deskriptif Lembar Analisis Kompetensi Pedagogik dalam Menyusun Rencana Pembelajaran.

\begin{tabular}{ccc}
\hline Skor Responden & Rentang Nilai & Kriteria \\
\hline $46-55$ & $83,64-100$ & Sangat baik \\
$37-45$ & $67,27-81,82$ & Baik \\
$28-36$ & $50,91-65,45$ & Cukup baik \\
$19-27$ & $34,55-49,09$ & Kurang baik \\
$9-18$ & $16,36-32,73$ & Tidak terencana \\
\hline
\end{tabular}

Tabel 2. Kriteria Deskriptif Lembar Analisis Kompetensi Pedagogik dalam Pelaksanaan Pembelajaran.

\begin{tabular}{ccc}
\hline Skor Responden & Rentang Nilai & Kriteria \\
\hline $80-95$ & $84,21-100$ & Sangat baik \\
$65-79$ & $68,42-83,16$ & Baik \\
$50-64$ & $52,63-67,37$ & Cukup baik \\
$35-49$ & $36,84-51,58$ & Kurang baik \\
$19-34$ & $20-35,79$ & Tidak baik \\
\hline
\end{tabular}

Tabel 3. Kisi-kisi instrumen angket faktor yang berperan dalam kompetensi Guru

\begin{tabular}{llc}
\hline No & \multicolumn{1}{c}{ Indikator } & No Angket \\
\hline 1. & Pengalaman kerja & 1 \\
2. & Pengalaman kerja di kelas X & 2 \\
3. & Pengalaman kerja di kelas XI & 3 \\
4. & Pengalaman kerja di kelas XII & 4 \\
5. & Frekuensi menerima sertifikasi & 5 \\
6. & Frekuensi mengikuti kegiatan MGMP & 6 \\
7. & Frekuensi mengikuti kegiatan seminar & 7 \\
8. & Frekuensi referensi buku pembelajaran lain & 8 \\
9. & Tingkat latar belakang pendidikan & 9 \\
10. & Frekuensi pemanfaatan sarana dan prasarana sekolah & 10 \\
\hline
\end{tabular}

HASIL DAN PEMBAHASAN Hasil Kompetensi Pedagogik

Data hasil kompetensi pedagogik guru dalam menyusun rencana proses pembelajaran (RPP) dapat dilihat pada Tabel 4. Kompetensi guru dalam pelaksanaan pembelajaran pada Tabel 5 .

Tabel 4. Kompetensi guru dalam Menyusun RPP

\begin{tabular}{llcc}
\hline No & \multicolumn{1}{c}{ Aspek yang diamati } & $\begin{array}{c}\text { Frekuensi Skor Total } \\
\text { Responden (\%) }\end{array}$ & Kriteria \\
\hline 1. & Menuliskan identitas mata pelajaran & 100 & Sangat baik \\
2. & Merumuskan indikator pembelajaran & 85,88 & Sangat baik \\
3. & Menentukan tujuan pembelajaran & 85,88 & Sangat baik \\
4. & Menentukan materi sesuai dengan kompetensi dasar & 81,18 & Sangat baik \\
& yang telah disusun & & \\
5. & Penentuan metode/model dan prosedur pembelajaran & & \\
& A. Menetukan metode/model pembelajaran yang & 72,35 & Sangat baik \\
\hline
\end{tabular}



B. Merancang prosedur pembelajaran untuk setiap pertemuan.
72,94
Sangat baik

6. Kegiatan pembelajaran

Kegiatan Awal
A. Membuka pelajaran
92,35
Sangat baik
Kegiatan Inti
B. Mengorganisasikan materi berdasarkan urutan dan kelompok
73,53
Sangat baik
Kegiatan akhir
C. Menutup pembelajaran
88,82
68,24
Sangat baik
Baik
buku, dan sejenisnya).
8. Menentukan jenis dan teknik instrumen penilaian.
61,76
Cukup baik

Tabel 5. Kompetensi Guru dalam Pelaksanaan Pembelajaran

\begin{tabular}{|c|c|c|c|}
\hline No & Aspek yang diamati & $\begin{array}{c}\text { Frekuensi Skor Total } \\
\text { Responden }(\%)\end{array}$ & Kriteria \\
\hline 1. & Mempersiapkan siswa untuk belajar. & 87,6 & Sangat baik \\
\hline 2. & $\begin{array}{l}\text { Melakukan kegiatan apersepsi dan menjelaskan } \\
\text { tujuan pembelajaran. }\end{array}$ & 97 & Sangat baik \\
\hline 3. & Penguasaan Materipelajaran & 97 & Sangat baik \\
\hline 4. & Mengaitkan materi dengan pengetahuan yang relevan & 93,4 & Sangat baik \\
\hline 5. & $\begin{array}{l}\text { Melaksanakan pembelajaran sesuai dengan } \\
\text { kompetensi (tujuan) yang akan dicapai dan } \\
\text { karateristik siswa. }\end{array}$ & 84 & Sangat baik \\
\hline 6. & Melaksanakan pembelajaran secara runtut & 70 & Baik \\
\hline 7. & Menguasai kelas & 85,2 & Sangat baik \\
\hline 8. & $\begin{array}{l}\text { Melaksanakan pembelajaran yang memungkinkan } \\
\text { tumbuhnya kebiasaan positif }\end{array}$ & 84,6 & Sangat baik \\
\hline 9. & $\begin{array}{l}\text { Melaksanakan pembelajaran sesuai dengan alokasi } \\
\text { waktu yang direncanakan }\end{array}$ & 95,3 & Sangat baik \\
\hline 10. & Menggunakan media secara efektif dan efisien & 67 & Cukup baik \\
\hline 11. & Melibatkan siswa dalam pemanfaatan media & 21,6 & Tidak baik \\
\hline 12. & $\begin{array}{l}\text { Menumbuhkan partisipasi aktif siswa dalam } \\
\text { pembelajaran }\end{array}$ & 83,4 & Baik \\
\hline 13. & Menunjukkan sikap terbuka terhadap respon siswa & 89,4 & Sangat baik \\
\hline 14. & $\begin{array}{l}\text { Menumbuhkan kecerian dan antusisme siswa dalam } \\
\text { belajar }\end{array}$ & 74 & Baik \\
\hline 15. & Memantau kemajuan belajar selama proses. & 85,2 & Sangat baik \\
\hline 16. & $\begin{array}{l}\text { Melakukan penilaian akhir sesuai dengan kompetensi } \\
\text { (tujuan) }\end{array}$ & 85,8 & Sangat baik \\
\hline 17. & $\begin{array}{l}\text { Menggunakan bahasa lisan dan tulis secara jelas, } \\
\text { baik, dan benar }\end{array}$ & 97,5 & Sangat baik \\
\hline 18. & $\begin{array}{l}\text { Melakukan refleksi atau membuat rangkuman } \\
\text { dengan melibatkan siswa }\end{array}$ & 68,2 & Baik \\
\hline 19. & $\begin{array}{l}\text { Melaksanakan tindak lanjut dengan memberi arahan, } \\
\text { atau kegiatan, atau tugas sebagai bagian } \\
\text { remedi/pengayaan }\end{array}$ & 65,8 & Cukup baik \\
\hline
\end{tabular}

\section{Hubungan faktor-faktor yang mempengaruhi Kompetensi Pedagogik}

Berdasarkan hasil analisis dengan menggunakan uji Chi-Square hubungan faktor-faktor dengan kompetensi pedagogik adalah: (1) faktor penerima sertifikasi dengan penyusunan rencana pelaksanaan pembelajaran (RPP) signifikan sebesar $0,025,(2)$ faktor mengikuti MGMP dengan pelaksanaan pembelajaran signifikan sebesar 0,012 dan (3) faktor latar 
belakang pendidikan dengan penyusunan RPP signifikan sebesar 0,037 .

1. Hasil Pengujian Chi-Square faktor penerima sertifikasi dengan penyusunan RPP.

\begin{tabular}{lrrr}
\hline & Value & df & \multicolumn{1}{c}{$\begin{array}{l}\text { Asymp. Sig. } \\
\text { (2-sided) }\end{array}$} \\
\hline Pearson Chi-Square & $9.310^{\mathrm{a}}$ & 3 & .025 \\
Likelihood Ratio & 12.700 & 3 & .005 \\
Linear-by-Linear & 8.480 & 1 & .004 \\
Association & & & \\
N of Valid Cases & 34 & & \\
\hline
\end{tabular}

2. Hasil Pengujian Chi-Square faktor mengikuti MGMP dengan pelaksanaan pembelajaran.

\begin{tabular}{lrcc}
\hline & Value & df & $\begin{array}{l}\text { Asymp. Sig. } \\
\text { (2-sided) }\end{array}$ \\
\hline Pearson Chi-Square & $8.816^{\mathrm{a}}$ & 2 & $.012)$ \\
Likelihood Ratio & 12.016 & 2 & .002 \\
Linear-by-Linear & 4.447 & 1 & .035 \\
Association & & & \\
N of Valid Cases & 34 & & \\
\hline
\end{tabular}

3. Hasil Pengujian Chi-Square faktor latar belakang pendidikan dengan penyusunan RPP

\begin{tabular}{lrcc}
\hline & Value & df & $\begin{array}{l}\text { Asymp. Sig. } \\
\text { (2-sided) }\end{array}$ \\
\hline Pearson Chi-Square & $6.585^{\text {a }}$ & 2 & .037 \\
Likelihood Ratio & 6.564 & 2 & .038 \\
Linear-by-Linear & 6.359 & 1 & .012 \\
Association & & & \\
N of Valid Cases & 34 & & \\
\hline
\end{tabular}

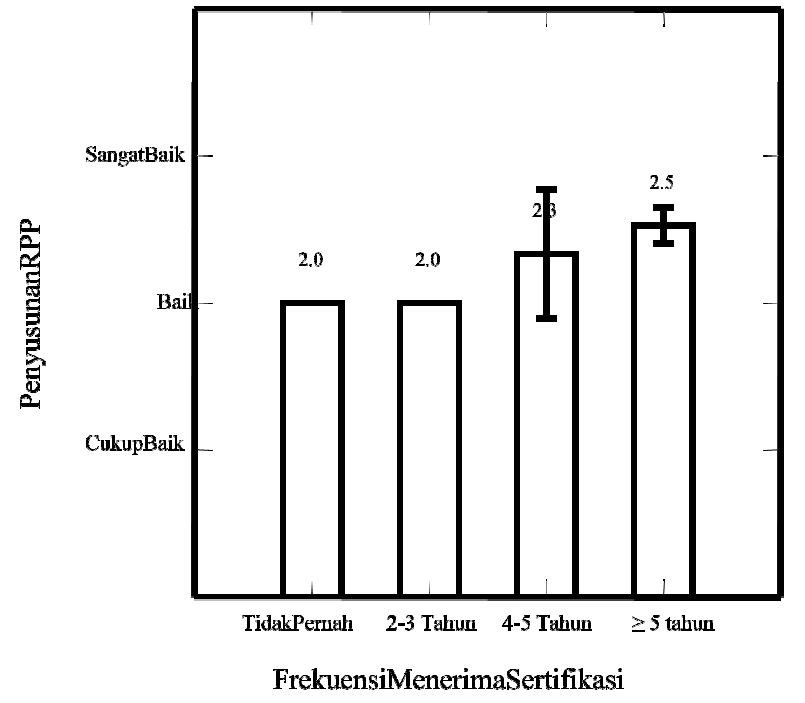

Gambar 1. Faktor Frekuensi Menerima Sertifikasi dengan penyusunan RPP

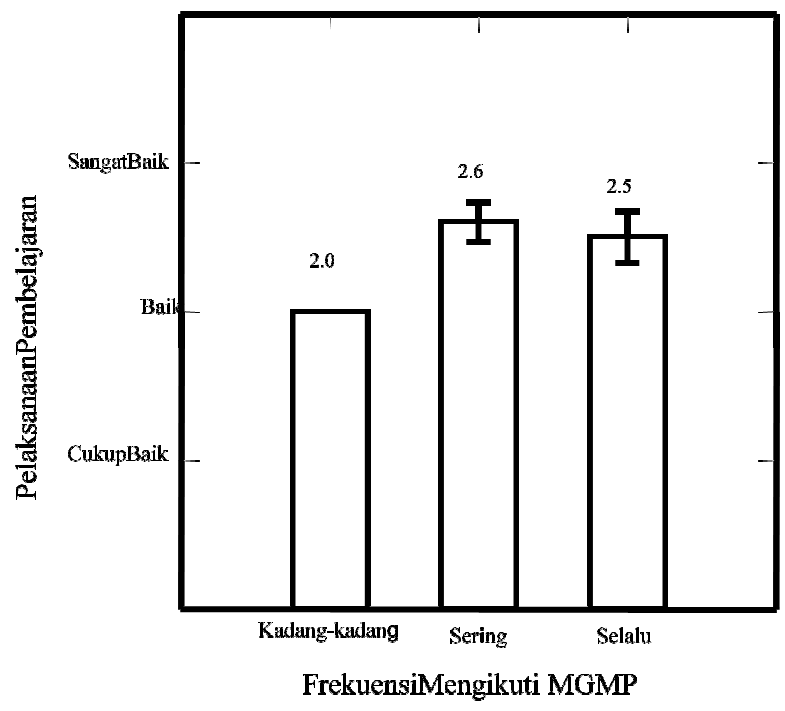

Gambar 2.Faktor Frekuensi Mengikuti Kegiatan MGMP dengan Pelaksanaan Pembelajaran.

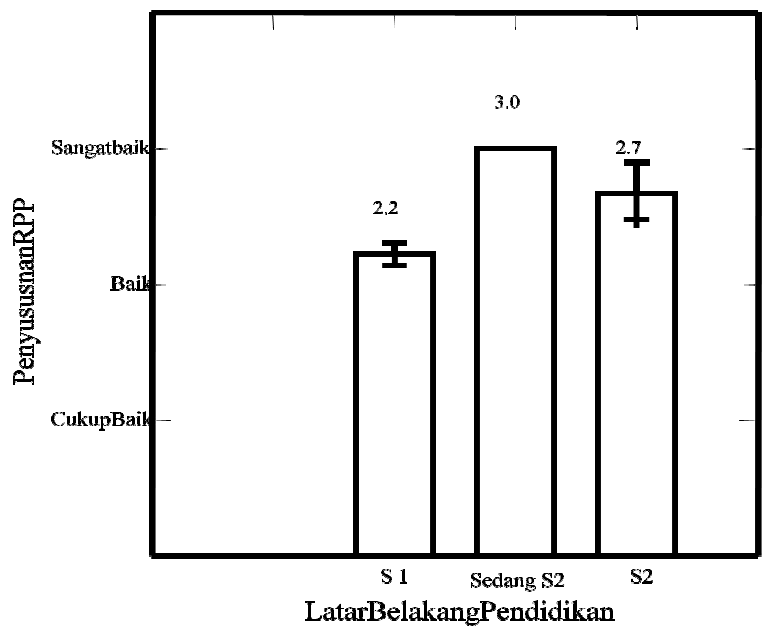

Gambar 3. Faktor latar belakang pendidikan dengan penyusunan RPP.

\section{PEMBAHASAN}

Kompetensi pedagogik dapat dilhat pada Tabel 4 dan Tabel 5. Kompetensi pedagogik dalam menyusun rencana pembelajaran diperoleh bahwa $32,35 \%$ sangat baik dan $67,65 \%$ baik. Kompetensi Pedagogik Guru dalam Menyusun Rencana Pembelajaran. Kompetensi pedagogik dalam pelaksanaan pembelajaran diperoleh bahwa $41,18 \%$ sangat baik dan $58,82 \%$ baik.

Berdasarkan hasil anaisis kompetensi pedagogik guru dalam pelaksanaan pembelajaran yang terdiri dari 19 item indikator yang digunakan, 12 indikator memperoleh hasil yang sangat baik dalam 
hal pelaksanaan pembelajaran. Hasil kompetensi pedagogik pelaksanaan pembelajaran dalam menggunakan media secara efektif dan efisien berdeskripsi cukup baik (67\%) serta aspek pengamatan melibatkan siswa dalam pemanfaatan media berkriteria tidak baik $(21,6 \%)$. Deskripsi pada indikator melibatkan siswa dalam pemanfaatan media yaitu memberi kesempatan siswa untuk menjelaskan materi dengan media, keterlibatan siswa dalam menggunakan media, keaktifan siswa dalam menggunakan media, kemampuan siswa menggunakan media dan media yang digunakan membantu siswa memahami materi.menginformasikan materi selanjutnya dan mengakhiri pembelajaran dengan menarik memperoleh hasil $(65,8 \%)$ dengan kriteria cukup baik. Total nilai ratarata penyusunan rencana pembelajaran (RPP) adalah $\bar{X}=80,32$ dengan kategori baik. Kegiatan pelaksananan pembelajaran mempunyai nilai rata-rata $\bar{X}=80,68$ dengan kategori baik.

Saragih (2008) mengatakan bahwa salah satu indikator kompetensi pedagogik, bahwa setiap guru harus membuat rencana dalam pelaksanaan pembelajaran dan mengoptimalkan proses belajar mengajar dalam mencapai mutu hasil belajar yang berkualitas. Hasil dari penelitian diperoleh bahwa dalam penyusunan rencana pembelajaran sudah sangat baik untuk tiaptiap indikator dalam instrumen yang digunakan. Muslich (2008) dimana komponen RPP minimal memuat identitas mata pelajaran, Standar Kompetensi (SK), Kompetensi Dasar (KD), indikator, tujuan pembelajaran, materi ajar, alokasi waktu, metode, kegiatan pembelajaran, penilaian dan sumber belajar.

MenurutKhan (2011) tranning menjadikan para guru mempunyai keterampilan dan kemampuan yang diperlukan dalam kegiatan belajar mengajar dan juga dapat mengubah sikap mereka dalam menjalankan kinerjanya. Menurut Sagala (2010) kualifikasi akademik guru adalah persyaratan minimal mengenai tingkat pendidikan formal dan keahlian/keilmuan, pangkat/golongan, jabatan, pengalaman kerja dan usia yang harus dipenuhi. Jadi kualifikasi akademik penting untuk menyandang jabatan fungsional yang profesional dan berkualitas.

Kesejahteraan mendudukin hal yang penting dalam meningkatkan kompetensi guru. Menurut Surya (2010) bahwa kesejahteraan guru berupa hak guru yaitu: (1) penghasilan diatas kebutuhan hidup minimum; (2) tunjangan yang melekat pada gaji; (3) tunjangan profesi; (4) tunjangan fungsional; (5) tunjangan khusus dan (6) maslahat tambahan yang terkait tugasnya sebagai guru. Penguasaan guru terhadap kemapuan teknologi juga merupakan faktor yang berperan dalam kegiatan pembelajaran.Menurut Rusman (2010) kriteria kompetensi profesional guru diantaranya adalah pemanfaatan teknologi informasi dan komunikasi untuk berkomunikasi dan mengembangkan diri.

Dari hasil analisis, faktor-faktor yang mempengaruhi kompetensi pedagogik dan kompetensi profesional adalah faktor pengalaman kerja mengajar biologi, menerima kompensasi, mengikuti kegiatan MGMP dan latar belakang pendidikan. Frekuensi menerima sertifikasi dengan penyusunan Rencana Proses Pembelajaran (RPP) sebesar $0,025 \leq 0,05$ dengan taraf signifikan. Frekuensi mengikuti kegiatan MGMP dengan pelaksanaan pembelajaran sebesar $0,012 \leq 0,05$ dengan taraf signifikan dan tingkat latar belakang pendidikan dengan penyusunan Rencana Proses Pembelajaran (RPP) sebesar 0,037 $\leq 0,05$ dengan taraf signifikan.Mulyasa (2008) menyatakan bahwa Forum Musyawarah Guru seperti Musyawarah Guru Mata Pelajaran (MGMP), guru dapat berdiskusi dan menelaah mengenai kesulitan serta dapat saling bertukar pikiran dalam merancang model pembelajaran dan implementasinya secara efektif dan efisien.

\section{SIMPULAN}

Kecenderungan kompetensi pedagogik guru Biologi SMA Se-Kota Binjai dalam (1) menyusun rencana pembelajaran adalah 11 orang $(32,35 \%)$ sangat baik, dan 23 orang $(67,65 \%)$ berada pada kategori baik. (2) Pelaksanaan pembelajaran adalah 14 
orang $(41,18 \%)$ berada kategori sangat baik dan 20 orang $(58,82 \%)$ berada pada kategori baik. Faktor-faktor yang mempengaruhi kompetensi pedagogic: tingkat latar belakang pendidikan dengan penyusunan Rencana Proses Pembelajaran (RPP) sebesar 0,037, frekuensi menerima sertifikasi dengan penyusunan Rencana Proses Pembelajaran (RPP) sebesar 0,025, dan frekuensi mengikuti kegiatan MGMP dengan pelaksanaan kegitan pembelajaran sebesar 0,012 .

\section{DAFTAR PUSTAKA}

Arikunto, S. 2008. Dasar-Dasar Evaluasi Pendidikan Edisi Revisi. Jakarta: Bumi Aksara.

Khan, NM. 2011. Need Assessment Of University Teachers For Professional Enhancement. Internasional Bussines and Management. 3(10).Diakses 23 Desember 2015.

Mulyasa, E. 2007. Standart Kompetensi Sertifikasi Guru. Bandung: RemajaRosdakarya.

Mulyasa, E. 2008. Menjadi GuruProfesional MenciptakanPembelajaranKreatifdanMenye nangkan. Bandung: Remaja Rosdakarya.

Rusman. 2010. Model-ModelPembelajaran. Jakarta: Rajawali Press.

Sagala, S. 2010. Supervisi untuk Profesional Guru. Bandung: Alfabeta.

Saragih, H. 2008. Kompetensi Minimal Seorang Guru dalam Mengajar.JurnalTabulara PPS Unimed. 5 (1):23-24. Diakses 30 Maret 2016.

Surya, M. 2010. Landasan Pendidikan Menjadi Guru yang Baik. Bogor:Ghalia Indonesia.Musfah, J. 2011. Peningkatan Kompetensi Guru Melalui Pelatihan dan SumberBelajar TeoriDan Praktik. Jakarta: Kencana.

Undang- Undang Republika Indonesia No14 Tahun 2005. Tentang Guru dan Dosen. Jakarta. 